\title{
Some issues of legal regulation of electronic commerce in the Russian Federation
}

\author{
Vladimir Belykh ${ }^{1}$, Anna Gubareva ${ }^{1}$, Larisa Dobrynina $^{1, *}$ and Lubov Gudovicheva ${ }^{1}$ \\ ${ }^{1}$ Ural State Law University, 21, Komsomolskaya st., Ekaterinburg, 620137
}

\begin{abstract}
Over the past ten years the Internet has developed into the global market space; now the commodities of online shops have already become accessible to the mass consumer on a global scale. The article analyzes the topical aspects of development of e-commerce in the Russian Federation and abroad (in the light of the experience of China). Special attention is devoted to the economic advantages of a segment of trade "business to customer" (B2C) and trans boundary-related legal risks that online-trade participants carry. The article outlines the prospects for the development of this sector in Russia in light of the "Strategy for the development of electronic commerce for the period until 2025".
\end{abstract}

\section{Introduction}

By the end of the XX century in connection with the massive use of the global telecommunication network - the Internet, information processes had begun acquiring international importance. It became clear that the more information the state has, the more likely that it can achieve strategic advantages and economic prosperity. The information capacity of the state and the society influences the high material wealth of the population; that is why the close attention in the world is paid to information, information resources and systems.

Nowadays more than half of the population of the Russian Federation (that is almost 80 million people) uses the Internet. For the country with a large territory that is located in 11 time zones it is of fundamental importance to ensure equal uninterrupted conditions for access of citizens and legal entities to the Internet.

N.A. Nikiforov, the Minister of Telecom and Mass Communications of the Russian Federation, notes that "the direct contribution of the Internet to the development of the economy of Russia is $2.2 \%$ of the gross domestic product (GDP). A much larger range of industries, that is estimated by experts at 11.6 trillion rubles (about 13\%), depends, in general, from information technologies and the Internet. Almost one-sixth of the Russian economy is the so-called Internet-dependent industries" [1].

\section{Materials and methods}

\footnotetext{
*Corresponding author: dovre@yandex.ru
} 
One of the elements of the new direction of the "Internet economy" is the "e-commerce", having been the most dynamically developed for the last five years. Almost all trade enterprises, retail trade facilities, banks have an "online" presence (that is their corporate websites), that increases trade and, thereby, helps receiving additional profit.

Nowadays the electronic commerce includes numerous online stores, electronic payment systems, online exchanges, online auctions, to name a few.

E-commerce includes several directions: "business to customer" (B2C), "business to business" (B2B), "consumer to consumer" or (C2C). If the first direction is electronic retail, the second one is electronic wholesale that includes all levels of informational and managerial cooperation between companies (usually commercial organizations). In the latter case it is the commercial interaction of households.

In the "business to customer" segment there are electronic trade enterprises, catalogs of products, trading lines, pre- and after-sales services and customer communities. In the segment "business to business" contracts are concluded and / or executed electronically on a bilateral basis or within a specialized electronic platform. Further the article will analyze, mainly, the Russian segment of "business to customer" (B2C).

The retail sale and purchase of goods on the territory of the Russian Federation is governed by the provisions of Chapters 27-29 and $\S \S 1$ and 3 of Chapter 30 of the Civil Code of the Russian Federation [2].

One type of retail sales contract is the sale of goods remotely to citizens for personal, family, household and other needs that are not related to business activity. In this case the contract in question is concluded on the basis of the buyer's awareness of the description of the goods proposed by the seller and contained in catalogs, brochures, booklets or presented in photographs or via the postal networks, telecommunication networks, including the telecommunication network - the Internet, as well as communication networks for broadcasting TV channels and (or) radio channels, or in other ways that exclude the possibility of the buyer's direct awareness of the goods or samples of the goods while concluding this contract [3]. While making a transaction both parties do not meet in person [4].

The sale of goods through online stores is one of the ways of distance trade. The use of such a sale significantly reduces the costs of any trading company: it is not necessary to buy (to lease) commercial premises, equipment, there is no need to use the services of intermediaries [5].

An online store is a website that sells goods via the Internet and that allows online users to create an order for purchase, to make a payment online and choose the way of delivery of orders.

Russian citizens and legal entities more often order goods abroad, most usually in the People's Republic of China. In 2017 China accounted for over $90 \%$ of all foreign postal deliveries, while the European Union accounted for only 3\% of international purchases. Already for the first three months of 2018 only "The Post of Russia" processed 95.7 million international trade orders that is $35 \%$ more than for the same period of 2017 . Every day more than 1 million mail deliveries are processed, the average cost of them is $22 €$ [6]. These data provide a clear picture of trends in the development of the Internet industry and its impact on the foreign economic activity of the country. It is important for Russia to gain a foothold in the group of countries that are actively approaching the leading countries of the world not merely in terms of GDP per capita, but also in terms of qualitative indicators of development: institutions, technologies, quality of life [7].

The greater part of the Russian market was conquered by the well-known Chinese public company working in the field of Internet commerce, Alibaba Group, which manages several structures, including:

- Alibaba.com (Alibaba China, Alibaba International) - the main asset of the company, a trading platform for organizations; 
- AliExpress.com - an online store selling goods in retail and small wholesale (with the option of free delivery by mail to China Post Air Mail; the feature of the service is that the seller receives money only after the delivery of the goods);

- Taobao. com - an online retail market, an online store and an online auction (all offered products can be purchased through AliExpress);

- Alipay - a platform for online electronic payments.

All of these companies use the same for all structures software for management of enterprises, as well as databases of goods and enterprises sorted by region and industry [8]. On 28August 2014 the company published an official report [9].According to this report it received \$ 2.54 billion as the revenue for the two quarters of $2014(50.81 \%$ at an annual rate and $9.41 \%$ compared to the first quarter), $\$ 1.99$ billion of net profit $(+182 \%$ on a year-onyear basis), the number of active buyers increased to 279 million (by $50.81 \%$ more in the annual comparison and by $9.41 \%$ compared with the previous quarter) [10].

\section{Results}

The sharp rise in retail trade with foreign counterparties in the Russian Federation is largely objective. In this instance certain customs aspects contributed to that. In 2018 a citizen is entitled to order a parcel with goods abroad and if its customs value does not exceed a sum equivalent to $1000 €$ per month and the total weight does not exceed 31 kilograms, the law does not require him to file a customs declaration and payment of customs duties [11].

An important point is that the Russian administrative requirements do not apply to foreign Internet companies.

Firstly, foreign Internet companies do not pay taxes provided for by the Tax Code of the Russian Federation [12] and customs duties when the goods cross the border. The current situation leads to the fact that it is even more profitable for Russian companies to create legal entities abroad and sell goods to Russian citizens from there [13].

Secondly, when selling goods in Russia foreign retailers are not required to certify (to confirm the quality and safety) of the goods sold. Since all postal deliveries are packed and closed, a lot of counterfeit goods cross the border.

Thirdly, the requirement to preserve the confidentiality of personal data of citizens-buyers does not extend to the foreign Internet companies. When entering into an agreement on the sale of goods remotely, the seller requests information from the consumer including his surname, name, patronymic, year, month, date and place of birth, address, number of the main document certifying his identity, information on the date of issue of the said document and the issuing body, as well as other information related to the personal data. In this regard the seller in Russia, that processes personal data of its customers, must ensure confidentiality, that is, to take the necessary organizational and technical measures to protect personal data from improper or accidental access to it, destruction, modification, as well as from other illegal actions [14]. In the event of failure to fulfill these statutory obligations, the seller is liable to the consumer in accordance with the norms of the Code of the Russian Federation of Administrative Offenses [15] and the Criminal Code of the Russian Federation [16]. These requirements of Russian administrative and criminal law do not apply to foreign participants.

Fourthly, there are national norms on the protection of consumers' rights on the territory of almost every country. Relationships in the field of retail trade on the territory of the Russian Federation are subject to the norms of the Law of the Russian Federation No. 2300-1 of 07.02.1992 "On Protection of Consumer Rights", which provides for legal remedies for purchasers. In particular, the consumer-citizen has the right to bring claims to the seller if the defects in the product are discovered, unless they are agreed by the seller, has the right to demand compensation for damage caused by defects in the goods, etc. Citizens of Russia have the right to defend their rights, both in judicial and in administrative procedure, by filing 
a complaint with the Federal Service for Surveillance on Consumer Rights Protection and Human Wellbeing (Rospotrebnadzor) [17]. The Department of the Sverdlovsk Rospotrebnadzor of the Russian Federation in 2017 deals with 298 complaints of citizens-buyers in the field of distance trade via the Internet. 18claims were prepared on questions of sale remotely- for the amount of 229 thousand rubles [18].

As it has been already mentioned above, a citizen concludes a contract of sale on the basis of acquaintance with the goods through the familiarization with advertising information. Such advertising must include information about the seller of these goods such as the name, location and state registration number of the record on the establishment of the legal entity; family name, first name, patronymic, the main state registration number of the record of the state registration of an individual as an individual entrepreneur [19]. The consumer does not always realize who he is buying the goods from and does not ask this question until there is some problem with the purchased product. The main categories of goods for which customer claims are received include technically complex consumer goods (computers, cell phones, etc.). The main violations pointed by consumers in the applications are the late delivery of goods or non-delivery of goods, inconsistency of the quality of the goods with advertisements and others.

However, Russian federal supervisory bodies do not have any authority in the area of international Internet trade. Citizens themselves cannot enjoy these rights because of various obstacles such as the language barrier, ignorance of the legislation of a foreign state, etc.

Russia seeks to protect the interests of its citizens, including in the field of international purchases. For example, in order to harmonize legislation on the protection of consumer rights of the Eurasian Economic Union member states in the field of distance trade the Recommendation of the Collegium of the Eurasian Economic Commission was created [20].

Trade via the Internet opens new horizons for business development and simultaneously generates new problems, not only legal ones, but also of economic, information and social nature.

The increase in sales in online trading caused the necessity for speed in the calculations and, as a result, led to the new financial products. The modern, created by decades, system of settlements through banks, including "Internet banking", in many respects have not proved itself. Settlements through banks imply the procedure of customer identification [21], compliance with anti-laundering legislation [22], control by the bank of each international payment (with supporting documents) [23], etc. As a response the global Internet network offered instant payments to its users by using new settlement means - electronic money [24] and cryptocurrency. The advantage of electronic money and cryptocurrency was also expressed in the fact that they are not subject to the usual forms of state control.

In the Russian Federation it is possible to pay to an online company by different ways: via the Internet, by electronic money, bank cards, bank transfer, etc[25]. While in Russia for a number of reasons cryptocurrency (in particular, bitcoin) is not expected to be used as a means of calculating [26].

Online trading, as the most rapidly growing and most promising area of the Russian market, is becoming the subject of the close attention of the tax authorities. So, in one of the cases the court concluded that the online seller had committed the tax offense. The court concluded that the seller's website had not corresponded to the characteristics of the online store as there had been no possibility for buyers to make payments through the website. The seller's bank account had not been synchronized or linked to the website [27].

In addition, since 1July 2017 in the Russian Federation online trading can be carried out only through cash registers that provide the ability to online data transfer to the Federal Tax Service (FTS) [28]. The new procedure ensures the online transfer of information on each calculation to the server of the Federal Tax Service. This technology allows to control the calculation and timeliness of payment of taxes and fees, to detect violations automatically, 
that makes illegal manipulation of revenue meaningless [29]. The payments for goods (works, services) sold with illegal use of an ordinary cash desk, without a fiscal drive, entails administrative responsibility under Part 2 of Art. 14.5 of the Code of the Russian Federation of Administrative Offenses.

The main result of 2017 is the following: a second after you have paid for the purchase by a card, the Federal Tax Service and the Federal Financial Monitoring Service (Rosfinmonitoring) [30] know what and where you bought it. Online cash registers almost have withdrawn the retail trade from the shadow: in 2016 tax officials "saw" 1 trillion rubles of revenue per month, in 2017 already - 1.5 trillion rubles. There forecasts are that Russia is following the path of Sweden where electronic control of the revenue through online cash desks has led to the fact that mostly only tourists pay in cash. In many stores it is possible to pay only by bank cards or by a smartphone, but cash are not accepted [31].

As some researchers notes, the sharp growth of online-trade in the world became the reason of appearance of a serious economic and social problem.

Thus, the volume of trade in the world's largest online store Amazon is rapidly growing. Only for the last six years its revenue has increased fivefold and reached $\$ 80$ billion. Consumers' preferences are such that the most convenient store is a sofa in the living room, and $20 \%$ of purchases are made from smartphones. If you can get to home anything you like quickly and with acceptable money, why should you waste your time shopping? Perhaps this is only a tribute to fashion, but in the age of the Internet residents of developed countries do not longer need a lot of shops.

And the other side of the situation is that those sellers who stayed in the usual format of the store in the shopping center and did not go online timely have an alarming tendency towards bankruptcy. In the US, more than 3,500 stores were closed during 2017, a phenomenon that experts called the "retail Apocalypse." According to analysts' forecasts, in five years in the US half of the shopping centers will be closed [32]. As a result, American Apparel is a bankrupt, 110 retail stores closed during the several months [33]; the main network of department stores for Americans of the middle-class Macy's is going to fire 10,000 people [34]; in 2017, the revenue of the British clothing retail Topshop fell 79\% [35]; the titanium of this market - H \& M -has the lowest sales for ten years [36]. This will affect the real estate market. According to analysts' forecasts, in five years in the US half of the shopping centers will be closed [37]. According to Moody's, as the credit component of this business is very large, in five years a debt gap will be open at the market, clothing retailers will start looking for sources of refinancing and, most likely, they will not be found. And then the credit bubble will burst. Retail clothing in its usual form is dying [38].

\section{Conclusions}

The dynamic information transformations in the modern society cause the need for their comprehensive analysis and understanding on the part of the legal science, which has not developed stable theoretical positions for the formation of legal bases for the closer integration of states in the international information sphere yet [39].

The process of the development and adoption of the international normative legal documents that define a trans boundary regime for the formation and use of information, including the information transmitted over global telecommunications networks, is currently discrete; their appearance is often caused by the spontaneous development of the information society and its contradictions.

The countries leading in the field of informatization are actively searching for ways to bring together international and national legislation that determines the main parameters of the legal regulation of the information exchange at the international level. This is evidenced by the experience of meetings at the high level of heads of national agencies in the field of 
information. So, in December 2015 D.A. Medvedev took part in the second world conference on the Internet issues and stated that "the Internet should remain an open, global and distributed resource in the future. At the same time the elements of state regulation and network management are necessary... Legal constructions do not keep up with the rapid development of technologies and the transfer of information. We have a lot of questions before us. How to guarantee the right of people to privacy? How to protect copyrights and other exclusive rights? Who will guarantee the uninterrupted operation of the critical Internet infrastructure? [40]". While there are "gray zones" in the normative legal field, the only result will be the fragmentation into the national segments of control over the Internet space. And the state's concern from the point of the legal regulation of this sphere is understandable.

In 2015 an important trend in the state's interest in the development of the Internet industry was the establishment of the Internet Development Institute (AIE), that was a continuation of the ideas and proposals said in October 2014 during the Russian Interactive Week (RIW2014) [41] and a long-term program for the development of the Russian part of the information and telecommunication network - the "Internet" and related industries.

In 2015 the countries of the Shanghai Cooperation Organization prepared the "Draft Rules of Conduct in the Field of International Information Security" [42], introduced at the UN, that helps to prevent conflicts in the information space [43].

The change in the vector of legislative initiatives of 2014-2015 is also evident, that was dictated by a complicated geopolitical situation, mutual sanctions and the need to ensure the digital sovereignty of the Russian Federation and to limit the information and technological dependence of our high-tech industry on the influence of the West.

In the President's Address to the Federal Assembly for 2016 [44], V.V. Putin outlined one of the projects that "can be the creation of some large private Russian companies in the field of electronic commerce, so that Russian goods are delivered via the Internet to all countries of the world [45]".

The goal of further development of foreign economic activity is seen in the fact that not only retail trade in goods should develop, but the foreign economic balance should not be skewed only towards imports of foreign goods. In the beginning of 2016 this proposal was supported by the businessman R. Baisarov who suggested creating a website that provides financial and legal support to help Russian companies attract investments and establish contacts with foreign markets and perform important functions, from ordinary trade to the accompaniment of new business projects of young Russian companies with the inventions or original ideas that will be delivered to the world market [46]. The main goal of this project is to ensure that any Russian-made product is protected in accordance with Western legislation.

In June 2016 Dakaitaowa.com launched its first online trading platform in China with $100 \%$ Russian investment of the Russian Export company, that is positioned as the "ideal solution for manufacturers of consumer products seeking to enter the Chinese market [47]". The idea of its development is connected to the fact that the annual growth rate of cross border e-commerce is on average $30 \%$ and the trade turnover between China and Russia by 2020 should reach $\$ 200$ billion. This website will deal with both wholesale sales to order distributors and other corporate customers in China, as well as retail sales to individuals from a warehouse in Shanghai, providing product manufacturers with related services - for example, transportation and logistics services and translation of necessary documentation and information about products [48]. The experience of creating the similar companies in China already exists, in particular, this is the above-mentioned Chinese company Alibaba Group.

The purpose of economic cooperation between Russia and China is to maximize the implementation of national interests, where the traditional national interests also have their expression in a context of the backdrop of economic globalization [49].

In October 2017 Russia proposed a «Strategy for the development of e-commerce for the period until 2025» [50], according to that it is planned to increase the share of e-commerce 
in the total volume of trade to $20 \%$ by 2015 . The proposed strategy is aimed at creating the additional market mechanisms that ensure the growth and development of e-commerce in Russia, the effective use of its resources and potential, including through:

- the removal of excessive prohibitions and the elimination of legal conflicts for electronic commerce that exist in the traditional trade;

- ensuring the effective regulatory and legal regulation of electronic transactions;

-the improvement of payment systems in the field of electronic transactions;

- providing the legal protection for participants of the electronic commerce;

- ensuring a balanced operating environment for Russian and foreign online stores that sell goods directly to individuals in Russia;

- the increase of cyber security in the field of electronic commerce in the domestic market and in the field of cross-border trade.

Undoubtedly, international trade as a segment of foreign economic activity will continue to develop actively, and, first of all, through the electronic commerce.

\section{References}

1. http://news.rambler.ru/economics/32389513/

2. The Civil Code of the Russian Federation N 51-FZ

3. Russian Rules for the sale of goods by remote means N 612 (2007)

4. European Convention on Cross Border Mail Order and Distance Selling, http://www.consultant.ru/cons/

5. T. Bursulaya, Finansovaya gazeta, 36 (2017)

6. T. Shadrina, Rossijskaya gazeta, 71(7534)

7. URL: http://ac.gov.ru/files/publication/a/14685.pdf

8. URL: https://m.lenta.ru/news/2014/11/21/taobao/

9. URL: http://alibaba.newshq.businesswire.com/press-release/alibaba-group-announcesmarch-quarter-2015-and-full-fiscal-year-2015-results

10. A.I. Bakharev, Group published its report for the second quarter of 2014, https://epepper.ru/news/alibaba-group-otchitalas-za-vtoroj-kvartal-2014-goda.html

11. URL: http://www.consultant.ru/cons/

12. The Tax Code of the Russian Federation (part one) of 31.07.1998 N 146-FZ, the Tax Code of the Russian Federation (part two) of 05.08.2000 N 117-FZ, http://www.consultant.ru/cons/

13. URL: http://www.cnews.ru/news/top/2017-03-24_onlajnmagaziny_v_rossii_ poluchat_osobyj_zakon

14. Russian Federal Law of 27 July 2006 No. 149-FZ

15. The Code of the Russian Federation of Administrative Offenses, N 195-FZ (2001)

16. The Criminal Code of the Russian Federation of 13.06.1996 N 63-FZ,

17. URL: http://rospotrebnadzor.ru

18. URL: http://www.interfax-russia.ru/Ural/report.asp?id=916296\&p=1

19. Russian Federal Law No. 38-FZ (2006)

20. Russian Recommendation of the Board of the Eurasian Economic Commission of November 21, 2017 No. 27, http://www.consultant.ru/cons/

21. URL: http://www.consultant.ru/cons/ 
22. "Agreement on counteraction to legalization (laundering) of the income from crime and financing of terrorism in the movement of cash and (or) monetary instruments across the customs border of the Customs Union "(Signed in Moscow on 19.12.2011)

23. Russian Federal law No. 115-FZ of 07.08.2001, http://www.consultant.ru/cons/

24. Order Rosfinmonitoring of 08.05.2009 № 103, http://www.consultant.ru/cons/

25. Russian Federal law No. 161-FZ of 27.06.2011, http://www.consultant.ru/cons/

26. Regulations on rules of implementation of money transfer (UTV. Bank of Russia 19.06.2012 N 383-P), http://www.consultant.ru/cons/

27. The draft Federal law №419059-7, http://www.consultant.ru/cons/

28. The resolution of the Seventeenth arbitration appeal court from 06.07.2017 No. 17АП7809/2017-AK in case №A71-16427/2016, http://www.consultant.ru/cons/

29. URL: https://www.nalog.ru

30. Information of the Federal Tax Service of Russia "On the transition to online cash departments", http://www.consultant.ru/cons/

31. http://www.fedsfm.ru

32. URL: https://secretmag.ru/opinions/v-2020-godu-my-budem-zhit-v-drugoi-rossii-izza-onlain-kass-i-fns.htm

33. URL: https://www.theguardian.com/us-news/2017/jul/22/mall-of-america-minnesotaretail-anniversary

34. URL: http://www.latimes.com/business/la-fi-american-apparel-layoffs-20170116story.html

35. URL: http://www.whio.com/business/retail-apocalypse-500-stores-more-close-thisyear/RzTeZhnIk13YIlF0skFV3H/

36. URL:http://www.bbc.com/news/business-40194955

37. URL:https://www.telegraph.co.uk/business/2017/12/15/hm-shut-stores-unexpecteddip-sales/

38. URL:https://secretmag.ru/trends/tendencies/golyi-apokalipsis-pochemu-magazinyodezhdy-zakryvayutsya-a-mass-market-teryaet-vyruchku.htm [in Russian].

39. A.V. Gubareva, A.N. Gulemin, Pravo i obshchestvo 2, 151-158 (2015)

40. URL:http://special.government.ru/news/21075/

41. URL:http://2014.russianinternetweek.ru

42. URL:http://www.mid.ru/ru/web/guest/organs/asset_publisher/AfvTBPbEYay2/content/ $\mathrm{id} / 916224$

43. URL: http://www.mid.ru/mezdunarodnaa-informacionnaa-bezopasnost//asset_publisher/UsCUTiw2pO53/content/id/916241

44. URL: http://www.kremlin.ru/events/president/news/53379

45. URL: http://www.kremlin.ru/events/president/news/47173

46. URL: http://www.rbc.ru/interview/business/10/02/2016/56b3934c9a794761393d0ae7?

47. URL: https://www.rbc.ru/rbcfreenews/572b0d9c9a79470673cdcbc0

48. http://www.rbc.ru/newspaper/2016/05/10/572b0d9c9a79470673cdcbc0

49. T.Chzhuchan, Akademicheskii zhurnal russkih issledovanii, 5 (2011)

50. URL: http://www.consultant.ru/law/hotdocs/51181.html/ 